\title{
Study on bronchoconstriction induced by histamine or serotonin in "Precision Cut Lung Slices" of the horse
}

\author{
Ann Kristin Barton ${ }^{1,3}$, Svenja Wabnitz ${ }^{1}$, Manfred Kietzmann² und Bernhard Ohnesorge ${ }^{1}$ \\ Clinic for Horses, University of Veterinary Medicine Hannover', Institute for Pharmacology, University of Veterinary Medicine Hannover ${ }^{2}$ and Equine Clinic, Free \\ University of Berlin ${ }^{3}$
}

\begin{abstract}
Summary
The aim of this study was to determine the effect of histamine and serotonin, as well as the influence of their inhibitors, on bronchoconstriction using equine precision-cut lung slices (PCLS), which were prepared from 5 horses affected by various degrees of small airway disease (SAD) and a sixth horse free of respiratory disease. Over all horses, histamine caused a concentration-dependent bronchoconstriction, with a median effective concentration of $1820 \mathrm{nM}$. The histamine induced bronchoconstriction could be inhibited by incubation with the $\mathrm{H} 1$-receptor antagonist cetirizine before the addition of histamine. However, incubation with the $\mathrm{H} 2$-receptor-antagonist ranitidine, the $\mathrm{H} 2$ and H3-receptor antagonist thioperamid and the H4-receptor antagonist JNJ7777120 had no significant effect. Serotonin induced a concentration-dependent bronchoconstriction in the horse without evidence of airway disease only. The serotonin-induced reaction in this case was inhibited when the PCLS was previously incubated in ketanserin. The possibility that respiratory disease could have a negative effect on the serotonin-receptor or the serotonin-induced bronchoconstriction pathway is discussed.
\end{abstract}

Keywords: Bronchoconstriction / histamine / serotonin / PCLS / horse / pulmology / chronic airway disease

\begin{abstract}
Untersuchung der durch Histamin oder Serotonin induzierten Bronchokonstriktion in "Precision Cut Lung Slices" des Pferdes
Das Ziel der Studie lag in der Untersuchung des Effektes von Histamin und Serotonin sowie des Einflusses ihrer Inhibitoren auf die Bronchokonstriktion an equinen Precision-Cut Lung Slices (PCLS), die von 5 Pferden mit chronisch obstruktiver Bronchitis (COB) und einem lungengesunden Pferd gewonnen worden waren. Histamin führte zu einer konzentrations-abhängigen Bronchokonstriktion bei einer effektiven Konzentration von 1820nM im Median. Die Histamin induzierte Bronchokonstriktion konnte durch die Inkubation mit dem $\mathrm{H} 1$-RezeptorAntagonisten Cetirizin vor der Zugabe von Histamin gehemmt werden. Im Gegensatz dazu hatte die Inkubation mit dem H2-Rezeptor-Antagonist Ranitidin, dem H3 und H4-Rezeptor Antagonist Thioperamid und dem H4-Rezeptor Antagonist JNJ7777120 keinen signifikanten Effekt. Serotonin führte nur bei dem lungengesunden Pferd zu einer konzentrations-abhängigen Bronchokonstriktion. Diese Serotonin-induzierte Bronchokonstriktion konnte durch die vorherige Inkubation mit Ketanserin gehemmt werden. Ein möglicher negativer Einfluss chronischer Atemwegserkrankungen auf den Serotonin-Rezeptor oder die Serotonin-induzierte Bronchokonstriktion werden diskutiert.
\end{abstract}

Schlüsselwörter: Bronchokonstriktion / Histamin / Serotonin / PCLS / Pferd / Pulmologie / chronische Atemwegserkrankung

\section{Introduction}

Small airway disease plays an important role in equine medicine. Affected horses often present with exercise intolerance (Deegen 1981), coughing and dyspnoea (van der Haegen et al. 2005). Affected horses show an increased reactivity to aerosolised particles such as fungal hyphae found in mouldy hay or straw. This may be due to epithelial damage and the exposure of nerve endings in the airway wall (Barnes 1996). Histological findings include epithelial necrosis and goblet cell hyperplasia with a loss of ciliated cells. A reduction in dynamic compliance and increased respiratory resistance is seen as a result of hypertrophy of the smooth airway muscles (Kaup et al. 1990), and in combination with mucus accumulation, mucosal oedema and fibrotic remodelling leads to an obstruction at the bronchiole level. Bronchodilating agents such as clenbuterol $(0.8 \mu \mathrm{g} / \mathrm{kg} \mathrm{BW})$ can be effective, however long term use leads to reduction in drug efficacy (Abraham et al. 2001). For the development of new therapeutics it is necessary to understand the inflammatory process and to avoid the development of irreversible changes.

The pathophysiology of small airway disease remains unknown, despite being the subject of many studies. Previous work has suggested the involvement of leucotrienes and histamine in the development of the disease (Berger et al.
1998, Creese et al. 1986, Wohlsen et al. 2001, Olszewski et al. 1999). The histamine inhalation provocation test (Klein and Deegen 1986) can be used to identify horses affected by nonspecific airway hypersensitivity. Decreases in dynamic compliance and increases in airway resistance, work of breathing and maximum intrathoracic pressure differences correlate to the severity of lung disease. Little is known about histamine-receptor-subtypes in the equine lung.

Serotonin acts as a hormone and a neurotransmitter on one of the serotonin receptors (5-HT). In the horse, much attention has been paid to the prokinetic effects of serotonin on the gastrointestinal tract (Delesalle et al. 2008) and its vasoconstrictive effects in laminitis (Menzies-Gow et al. 2008, Zerpa et al. 2007), whereas its effects on equine small airways has not been studied ex vivo. The PCLS technique was described by Martin et al. (1996) and Wohlsen et al. (2001) in mice and human lung tissue. Vietmeier et al. (2007) were the first to use the technique for equine lung, and it was used for several earlier studies by our group (Schwalfenberg 2007, Barton et al. 2010a, Barton et al. 2010b, Fugazzola et al. 2012). The PCLS technique enables ex vivo investigation of airway contraction in response to drugs. This technique also allows a number of drugs to be tested on the same lung tissue reducing the number of animals used. 


\section{Material and Methods}

Animals

Fourteen horses, euthanized for reasons unrelated to respiratory disease, were included in the study. Horses were excluded from the study if they had cardiovascular abnormalities or had undergone general anaesthesia 72 hours prior to euthanasia. A clinical examination of the respiratory tract, arterial blood gas analysis, bronchoscopy and tracheobronchial cytology were performed on the day before euthanasia. Precision-cut lung slices of six horses were randomly assigned to be used for histamine and serotonin experiments and results are presented in this paper.

\section{Precision-cut lung slices}

Immediately following euthanasia with pentobarbital 300 $\mathrm{mg} / \mathrm{kg} \mathrm{KGW} \mathrm{IV} \mathrm{the} \mathrm{thoracic} \mathrm{cavity} \mathrm{was} \mathrm{opened} \mathrm{at} \mathrm{the} \mathrm{right}$ 7 th intercostal space. The accessory lobe was identified medial to the caudal vena cava and with the help of an extractor developed by Vietmeier et al. (35) was separated from the rest of the lung. Through a cannula the lobe was filled with a low melting-point agarose solution (1,5\% final concentration) and placed on ice for 20 minutes to solidify the agarose for cutting. The lobe was then cut in $1 \mathrm{~cm}$ thick slices and intact bronchiolar rings were excised with the help of a sharpened metal tube. The tissue cores were cut in $400 \mu \mathrm{m}$-thick slices (PCLS) with a Krumdieck tissue slicer Model MD 4000 (Alabama Research and Development, A Division of Alabama Specialty Products, P.O. Box 739 Mundford, AL 36268).

\section{Culture medium}

PCLS were placed in 12-well plates and covered with $1 \mathrm{ml}$ RPMI-1640-Medium. The RPMI-1640-Medium is a bicarbonate buffer and nutrition source containing amino acids and vitamins. The slices were incubated at $37^{\circ} \mathrm{C}$ during which time the medium was replaced three times initially to remove the agarose and cell debris and then at intervals of ten, twenty and thirty minutes.

\section{Assessment of viability}

Viability of the equine bronchioli was assessed by degree of bronchoconstriction induced by the potent bronchoconstrictor methacholine $\left(10^{-5} \mathrm{~mol} / \mathrm{l}\right)$. The bronchoconstriction of the slices was expressed as the percentage of contraction after addition of methacholine compared to the initial cross-sectional area. Bronchioli were considered viable and included in the study if they demonstrated at least a $50 \%$ reduction in crosssectional area and relaxed following removal of the methacholine by serial replacement with the buffering-solution.

\section{Studies on bronchoconstriction and its inhibition}

Histamine acts on each of the four histamine receptors. It was used in rising concentration, from $10^{-7}$ to $10^{-4} \mathrm{~mol} / \mathrm{l}$, to induce contraction of the bronchioli. To see if the induced contraction could be inhibited, antagonists were tested. Each of the antagonists used inhibits one receptor, with the exception of thioperamid which acts both on the $\mathrm{H3}$ - and $\mathrm{H} 4$-receptors. Cetirizine was used to antagonise the $\mathrm{H} 1$-receptor, ranitidine for the H2-receptor and JNJ7777120 for the H4-receptor. The antagonists were used at a concentration of $10^{-5} \mathrm{~mol} / \mathrm{l}$. Additionally, to check for the presence of $\mathrm{H} 4$-receptors within equine lung, 4-methylhistamine, a $\mathrm{H} 4$-receptor agonist, was tested on the PCLS of three horses.

Serotonin was used in serial concentrations from $10^{-8}$ to $10^{-5} \mathrm{~mol} / \mathrm{l}$. A single serotonin receptor antagonist, ketanserin $\left(10^{-5} \mathrm{~mol} / \mathrm{l}\right)$, was used.

Serial solutions of increasing concentrations of histamine and serotonin were added to the PCLS to determine the maximum degree of contraction. This step was repeated a second time following a 30 minute incubation of the PCLS in RPMI-medium containing the specific receptor antagonist. The bronchiole lumen was photographed using an inverted microscope two minutes after each change in concentration of the bronchoconstricting agent. The area of the bronchial lumen was measured with a computer program ("scion image" version beta 4.0.2) after conversion of the image to grey scale tiff-format to increase contrast of bronchiole borders. The cross sectional area of each bronchiole before the addition of a mediator was defined as $100 \%$. Bronchoconstriction was then expressed as the reduction of bronchial lumen (cross-sectional area) from this initial state as described by Barton et al. (2010a).

\section{Statistics}

The statistical analysis utilised the original cross-sectional area size data and was analyzed by a non parametric ANOVA test and a Dunn's test in which the degree of bronchoconstriction induced by each mediator was compared to the initial state. In contrast to this, the graphics were constructed using the percentage data. In this way different airway sizes could be visually compared.

\section{Results}

Four of the 14 horses were found to have severe findings compatible small airway disease as defined by Ohnesorge et al. (1998). Nine horses had mild findings and only one horse had no signs of respiratory disease.

35 viable PCLS from the accessory lobe of 6 horses (1 severely affected, 4 mildly affected, 1 free of respiratory disease) were chosen to be included in the described subsequent tests. As described in former studies (Vietmeier et al. 2007, Barton et al. 2010a) PCLS remain viable for up to 72 hours allowing accurate and precise repetition of contractility analysis.

In the present study histamine caused a concentration-dependent bronchoconstriction with a median effective concentration (EC50) of $1820 \mathrm{nM}$ (fig. 1a). A significant contraction $(p=0.0005)$, compared to the initial cross-sectional area, could be seen after addition of $10^{-5} \mathrm{~mol} / \mathrm{l}$ of histamine. This bronchoconstriction was inhibited by the addition of cetirizine, a $\mathrm{Hl}$-receptor antagonist (fig. $1 \mathrm{~b}$ and fig. 2). In contrast, the $\mathrm{H} 2-$ - $\mathrm{H} 3$ - and $\mathrm{H} 4$-receptor antagonists had no effect (fig. 
1c-e). Corresponding to this finding, the addition of 4 methylhistamine $\left(10^{-5} \mathrm{~mol} / \mathrm{l}\right)$, which acts on $\mathrm{H} 4$-receptors, did not induce a bronchoconstriction (fig. 1f).

Only PCLS from one out of six horses exposed to serotonin showed concentration dependent bronchoconstriction with a median effective concentration (EC50) of $82 \mathrm{nM}$ occurring between the addition of serotonin in a concentration of $10^{-6}$ and $10^{-5} \mathrm{~mol} / \mathrm{L}$ (fig. 3b). A significant contraction $(p=0.028)$, compared to the initial cross-sectional area, could be seen after addition of $10^{-5} \mathrm{~mol} / /$ of serotonin. This serotonin induced contraction was inhibited in this single horse by the serotonin receptor antagonist ketanserin $\left(10^{-5} \mathrm{~mol} / \mathrm{L}\right)$ (fig. 3c). It was the only horse in this study free of respiratory disease. a

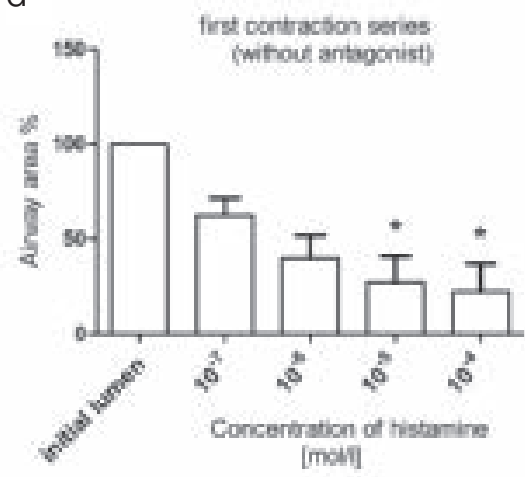

d

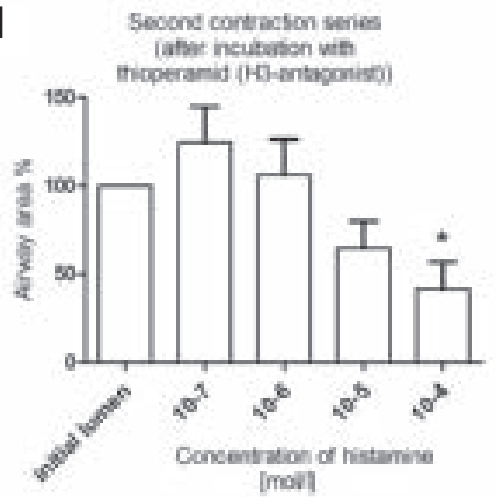

b
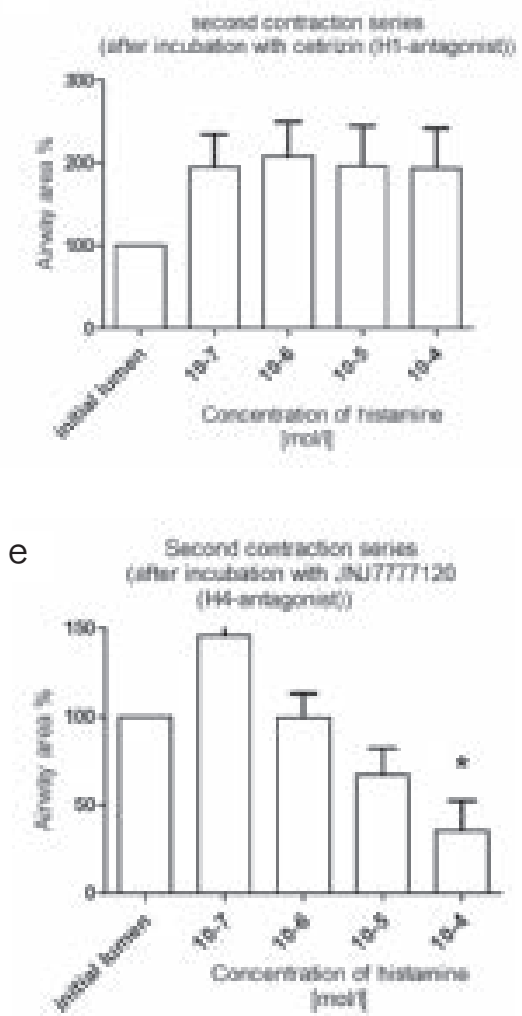

C

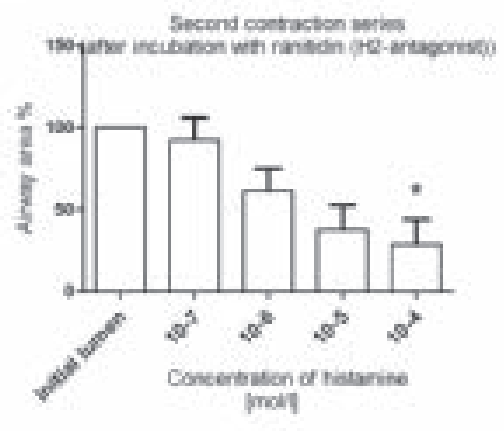

f

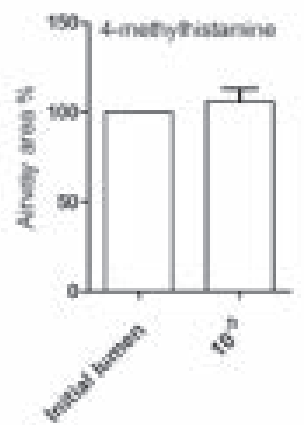

Fig. 1 Concentration dependent bronchoconstriction in equine precision-cut lung slices induced by histamine (fig. 1a), 4-methylhistamine (fig. If) and the effect of histamine-antagonists (fig. 1 b-e). Values are expressed as a percentage of initial bronchiole lumen cross-sectional area.
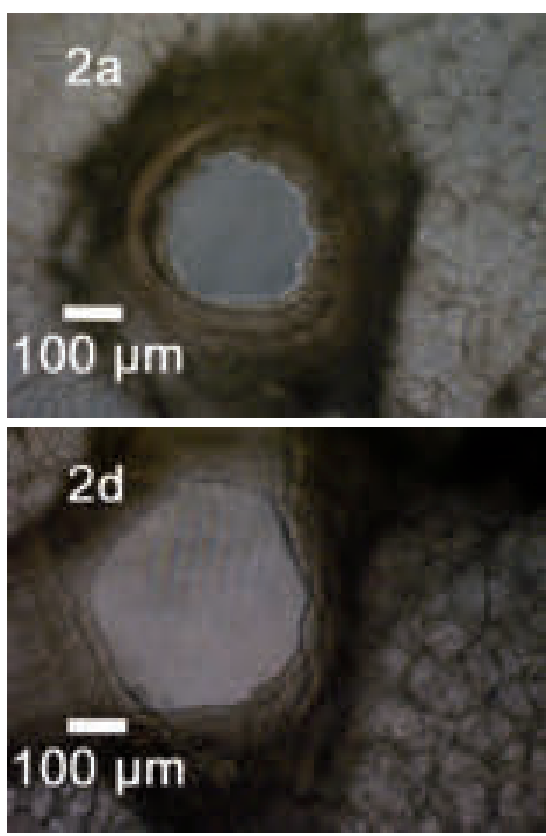
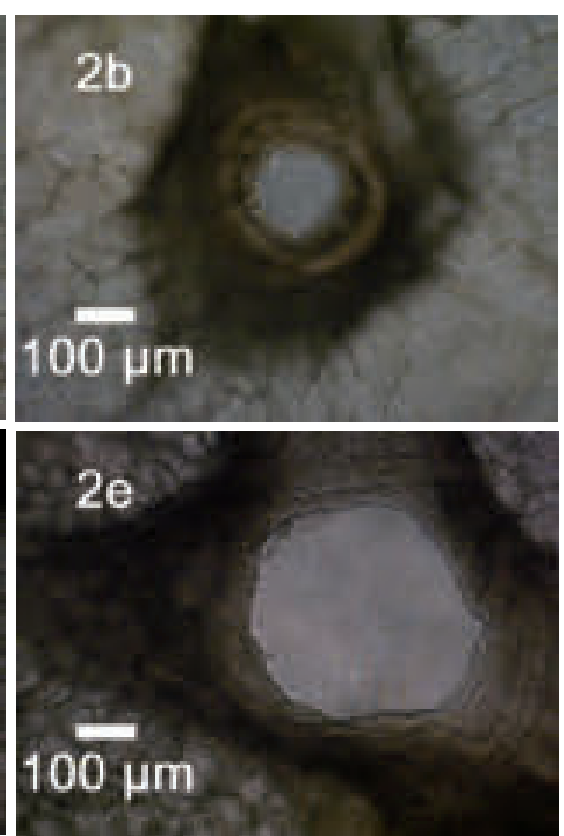
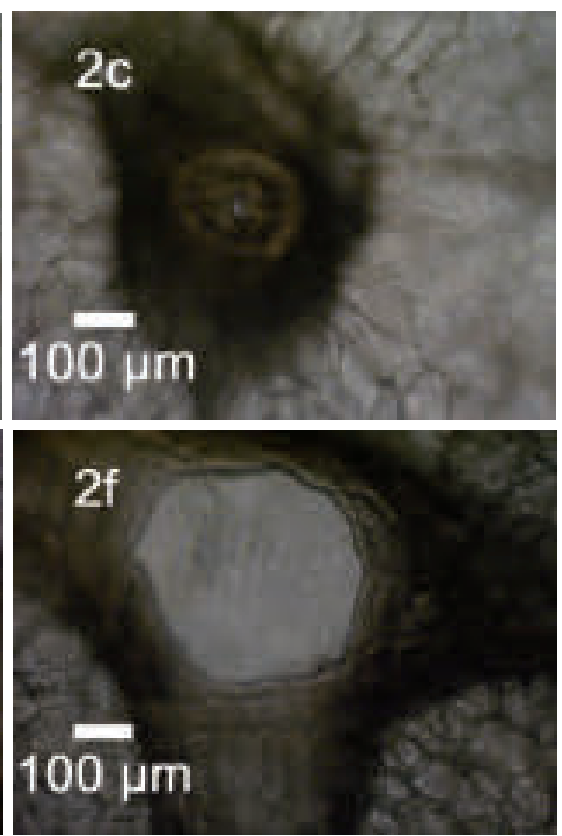

Fig. 2 Microscopic images of precision-cut lung slices (PCLS) before (2a) and after exposure to histamine in different concentrations (2b $10^{-7} \mathrm{~mol} / \mathrm{l}$ and $\left.2 \mathrm{c} 10^{-4} \mathrm{~mol} / \mathrm{l}\right)$. In figures $2 \mathrm{~d}$ - $\mathrm{f}$ the influence of the incubation with the $\mathrm{H} 1$-receptor antagonist cetirizin is shown (2d before exposure to histamine, 2 e $10^{-7} \mathrm{~mol} / \mathrm{l}$ and $2 \mathrm{f} 10^{-4} \mathrm{~mol} / \mathrm{l}$ ) 

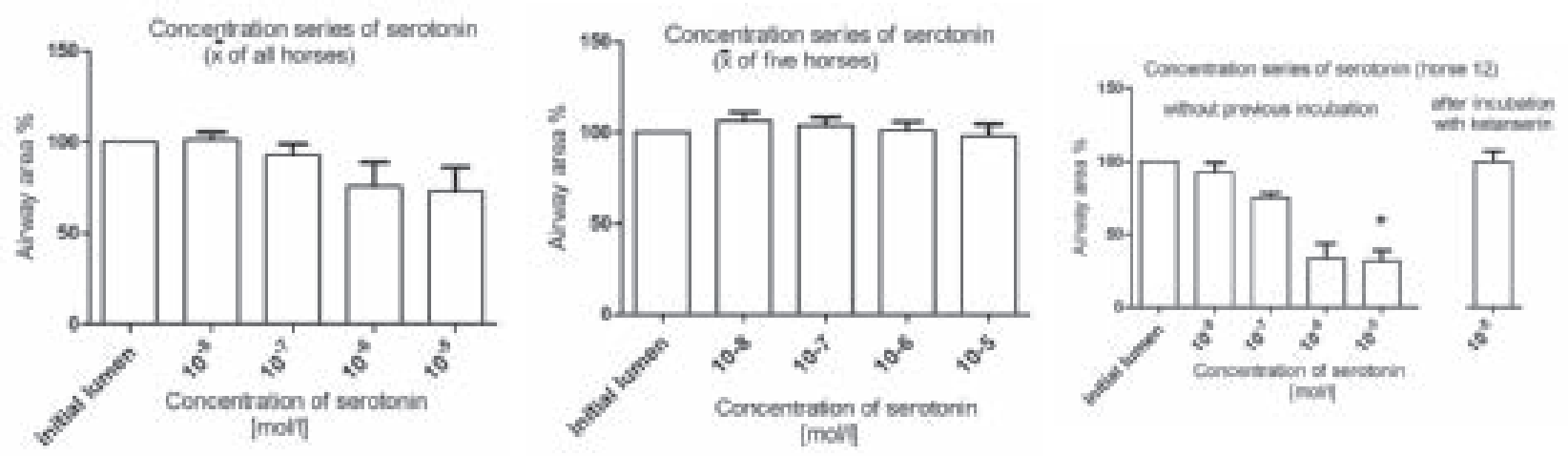

Fig. 3 Effect of serotonin on precision-cut lung slices (PCLS) from all 6 horses (fig. 3a) and from 5 horses affected by lower airway disease compared to the concentration depending contraction induced in one horse free of lower airway disease (fig. 3c). This contraction could be inhibited by a previous incubation with ketanserin $\left(10^{-5} \mathrm{~mol} / \mathrm{l}\right)$ (fig. $\left.3 \mathrm{c}\right)$. Values are expressed as a percentage of initial bronchiole lumen crosssectional area.

\section{Discussion}

Histamine induces bronchoconstriction in humans, guinea pigs and marmosets, a new world monkey. Previous work has demonstrated the high sensitivity of guinea pigs' (EC50 $=217$ nM) (Ressemeyer et al. 2006) and marmosets' (EC50 $=425$ nM) (Seehase et al. 2011 ) small airways to histamine. Studies on the horse provided variable results. Vietmeier et al. (2007) and Barton et al. (2010b) demonstrated a high sensitivity to histamine ( $E C 50=200 \mathrm{nM}$ ) which is comparable to that described in guinea pigs (EC50 $=217 \mathrm{nM}$ ) (Ressemeyer et al. 2006). In contrast to former studies, horses appear to be less sensitive in the present study. This reaction could be compared to human small airways ( $E C 50=2710 \mathrm{nM}$ ) (Seehase et al. 2010). Therefore, it is difficult to predict how histamine acts in the horse and to which other species they are comparable.

Bronchoprovocation by histamine inhalation has provided different results in former studies; therefore the effect of histamine in the pathogenesis of small airway disease remains controversial. Whereas Klein and Deegen (1986) demonstrated decreased dynamic compliance and increased respiratory resistance in horses suffering from small airway disease compared to healthy individuals with the Histamine-Inhalation-Provocation-Test (HIPT), this could not be confirmed by Perkins et al. (2008) using the same protocol. Traub (2005) also found only minimal bronchoconstriction in response to inhalation of histamine, whereas Hoffmann (2002) demonstrated increased reactivity to histamine inhalation even during clinical remission. In the current ex vivo study, histamine induced a statistically significant, concentration dependent bronchoconstriction independent of severity of disease and in the healthy horse, which could be inhibited by the $\mathrm{H} 1$-receptor antagonist cetirizine. This finding further supports the clinical study by Olsen et al. (2007) on horses, who also found cetirizine to be effective. Although pharmacokinetic studies demonstrated a short half-life of cetirizine in horses (Olsen et al. 2007), therefore requiring twice daily application, the ease of oral administration improves usability of cetirizine.

Antihistamines have been found to be ineffective in the treatment of small airway disease (Barnes 2001) because of a low receptor affinity and a $\mathrm{pH}$-dependent receptor binding. During an allergic reaction the resultant drop in $\mathrm{pH}$ means leads to decreased receptor-binding of antihistamines (Wellmann 2007).

In the present study the $\mathrm{H} 2$ - and $\mathrm{H} 3$-receptor antagonists ranitidine and thioperamid had no inhibitive effect on histamine-induced broncoconstriction, which could be explained by their lack of action on $\mathrm{H} 1$-receptors. Ranitidine is used in equine medicine to reduce gastric acids (Löscher 2006). The $\mathrm{H} 2$-receptor could be found in small airways of humans, sheep, pigs, guinea pigs and horses (Chand et al. 1979). Whereas Johnson (1998) declared the $\mathrm{H} 2$-receptor to be an inhibitory receptor which induced relaxation of small airways, Olszewski et al. (1999b) supposed no effect of it.

Thioperamid is an H3-receptor antagonist used in human medicine for sleep disorders, migraine and adiposity (Leurs et al. 2005). In horses, a H3-receptor antagonist was proven to increase tissue sensibility for histamine which led to airway relaxation (Olszewski et al. 1999b).

The $\mathrm{H} 4$-receptor was characterized for the first time in 2000 (Nakamura et al. 2000). In human airways it was found in low density (Akdis et al. 2006). In mice, the highly selective H4-receptor-antagonist JNJ7777120 (1 - [(5-Chloro- 1 Hindol2-yl)carbonyl]-4-methylpiperazine) leads to a reduced immigration of inflammatory cells into affected bronchial areas (Fung-Leung et al. 2004). The H4-receptor-agonist H4methylhistamine induces relaxation of the trachea and small airways (Chand et al. 1979). So far, there is no evidence for the existence of a $\mathrm{H} 4$-receptor in equine small airways. In the

\begin{tabular}{lccccc}
\hline Table 1 & Mediators are able to induce bronchoconstriction & & & \\
\hline & Horse & Man & Guinea pig & Marmoset & Mouse \\
\hline Histanime & + & + & + & + & - \\
Serotonine & $(+)$ & - & + & - & + \\
\hline
\end{tabular}

+ : effective; $-:$ ineffective; $(+)$ : partially effective 
present study the absence of $\mathrm{H} 4$-receptors was confirmed on the one hand by the missing bronchoconstriction induced by 4-methylhistamine and on the other hand by the $\mathrm{H} 4$-receptor antagonist JNJ7777120, which had no bronchoconstriction inhibiting effect.

In conclusion, bronchoconstriction in horses can be induced by the action of histamine on the $\mathrm{Hl}$-receptor and can be inhibited ex vivo by the $\mathrm{H} 1$-antihistamine cetirizine. The $\mathrm{H} 2$ and H3-receptor may exist in equine small airways but does not induce bronchoconstiction. The $\mathrm{H} 4$-receptor is supposed to be absent, but further work needs to be done to prove this theory.

Previous work demonstrated that serotonin is able to induce a concentration dependent bronchoconstriction in rodents (De Swert et al. 2007). The existence of serotonin receptors in airway smooth muscles of these animals is proven. In the present study there was no evidence of serotonin-induced bronchoconstriction in five of six horses. In humans and marmosets serotonin does not induce a reaction either (Seehase et al. 2010). Guinea pigs show a high sensitivity for serotonin (EC50=69 nM) [17], which can be compared to the single horse which responded to its addition ( $E C 50=82 \mathrm{nM})$. Serotonin did induce bronchoconstriction in murine airways but they seemed to be less sensitive than those of other species (EC50 =2000 nM, Held et al. 1999).

In the single case, in which serotonin-induced bronchoconstriction occurred, the horse was found to be free of respiratory disease. This contraction was inhibited by the serotonin receptor antagonist ketanserin. Unfortunately only one horse free of respiratory disease was included in this study, so it remains speculative that serotonin receptors might be present in the equine lung and that bronchoconstriction can only be induced in healthy horses. It might also be possible that respiratory disease may have a negative effect on the density of serotonin-receptors.

It has been shown that horses affected by small airway disease do not react to the addition of an allergen with an immediate allergic reaction (early-phase response) but an exaggerated late-phase response. Only in healthy horses an immediate allergic reaction can be seen (Deaton et al. 2007). This suggests that the reaction of a healthy horse to an inhaled allergen is a protective mechanism which avoids the distribution of the allergen in small airways. This bronchoconstriction may be mediated by serotonin, but further studies involving greater case numbers are required. Nevertheless, it is seems that the serotonin effect or pathway might be disabled during the development of small airway disease.

\section{Acknoledgements}

The authors declare that they have no competing interests.

\section{References}

Abraham G., Brodde O. E. and Ungemach F. R. (2001) Clenbuterolvermittelte Herabregulation lymphozytärer beta2-Adrenozeptoren bei Pferden: Dexamethason verhindert den tachyphylaktischen Effekt von Clenbuterol. Tierärztl. Praxis 29, 366-372
Akdis C. A. and Simons F. E. (2006) Histamine receptors are hot in immuno-pharmacology. Eur. J. Pharmacol. 533, 69-76

Barnes P. J. (1996) Pathophysiology of asthma. Br. J. Clin. Pharmacol. 42, 3-10

Barnes P. J. (2001) Histamine and serotonin. Pulm. Pharmacol. Ther. 14, 329-339

Barton A. K., Niedorf F., Gruber A. D., Kietzmann M. and Ohnesorge B. (2010a) Pharmacological studies of bronchial constriction inhibited by parasympatholytics and cilomilast using equine precision-cut lung slices", Berl. Münch. Tierärztl.Wschr. 5, 229-235

Barton A. K., Niedorf F., Kietzmann M. and Ohnesorge B. (2010b) Pilotstudie zur passiven Sensibilisierung an Precision-Cut-Lung-Slices (PCLS) des Pferdes. Pferdeheilkunde 26, 789-796

Berger P., Walls A. F., Marthan R. and Tunon-de-Lara J. M. (1998) Immunoglobulin E-induced passive sensitization of human airways: an immunohistochemical study. Am. J. Respir. Crit. Care Med. 157, 610-616

Chand N., Eyre P. and Deroth L. (1979) Pharmacological study of bovine airways. Evidence for excitatory and inhibitory effects of histamine". Can. J. Com.p Med. 43, 384-391

Creese B. R. and Temple D. M. (1986) The mediators of allergic contraction of human airway smooth muscle: a comparison of bronchial and lung parenchymal strip preparations. Clin. Exp. Pharmacol. Physiol. 13, 103-311

Deaton C. M., Deaton E., Jose-Cunilleras E., Vincent T. L., Baird A. W., Dacre K. and Marlin D. J. (2007) Early onset airway obstruction in response to organic dust in horse. J. Appl. Physiol. 102, 1071-1077

Deegen E. (1981) Massive Intravenous Infusions - a Novel Secretolytic Therapy for Horses with Chronic Obstructive Pulmonary-Disease (COPD). Proceedings of the Annual Convention of the American Association of Equine Practitioners 27, 27-32

Delesalle C., van de Walle G. R., Nolten C., Ver Donck L., van Hemelrijck A., Drinkenburg W., de Bosschere H., Claes P., Deprez P., Lefere L., Torfs S. and Lefebvre R. A. (2008) Determination of the source of increased serotonin (5-HT) concentrations in blood and peritoneal fluid of colic horses with compromised bowel. Equine Vet J. 40, 326-331

De Swert K. O., Lefevre R. A., Pauwels R. A. and Joos G. F. (2007) Role of the tachykinin NK(1) receptor in mediating contraction to 5 -hydroxytryptamine and antigen in the mouse trachea. Pulm. Pharmacol. Ther. 20, 588-595

Fugazzola M., Barton A. K., Niedorf F., Kietzmann M. and Ohnesorge B. (2012) Non-genomic action of beclomethasone dipropionate on bronchoconstriction caused by leukotriene $\mathrm{C} 4$ in precision cut lung slices in the horse. B. M. C. Vet. Res. 2012 Sep 10;8:160. doi: 10.1186/1746-6148-8-160

Fung-Leung W. P., Thurmond R. L., Ling P. and Karlsson L. (2004) Histamine $\mathrm{H} 4$ receptor antagonists: the new antihistamines? Curr. Opin. Investig. Drugs 5, 1174-1183

van der Haegen A., Kunzle F., Gerber V., Welle M., Robinson N. E. and Marti E. (2005) Mast cells and IgE-bearing cells in lungs of RAO-affected horses. Vet. Immunol. Immunopathol. 108, 325334

Held H. D., Martin C. and Uhlig S. (1999) Characterization of airway and vascular responses in murine lung. Br. J. Pharmacol. 126, $1191-1199$

Johnson M. (1998) The beta-adrenoceptor. Am. J. Respir. Crit. Care. Med. 158, 146-153

Kaup F. J., Drommer W. and Deegen E. (1990) Ultrastructural findings in horses with chronic obstructive pulmonary diesease (COPD) I: Alterations of the larger conducting airways. Equine Vet. J. 22, 343-348

Klein H. J. and Deegen E. (1986) Histamine inhalation provocation test: method to identify nonspecific airway reactivity in equids. Am. J. Vet. Res. 47, 1796-800

Leurs R. B., Timmermann R. A. and De Esch I. J. (2005) The histamine $\mathrm{H} 3$ receptor: from gene cloning to $\mathrm{H} 3$ receptor drugs. Nat. Rev. Drug Discov. 4, 107-120 
Löscher W. (2006) Pharmaka mit Wirkung auf periphere Mediatoren In: Löscher W., Ungemach F. R., Kroker R. (Ed.) Lehrbuch der Pharmakologie und Toxikologie für die Veterinärmedizin; Verlag Enke Stuttgart, pp. 56-63

Martin C., Uhlig S. and Ulrich V. (1996) Videomicroscopy of methacholine-induced contraction of individual airways in precision-cut lung slices. Eur. Respir. J. 9, 2479-2487

Menzies-Gow N. J., Sepulveda M. F., Bailey S. R., Cunningham F. M. and Elliott J. (2008) Roles of thromboxane A2 and 5-hydroxytryptamine in endotoxin-induced digital vasoconstriction in horses. Am. J. Vet. Res. 69, 199-207

Nakamura T., Itadani H., Hidaka Y., Ohta M. and Tanaka K. (2000) Molecular cloning and characterization of a new human histamine receptor HH4R. Biochem. Biophys. Res. Commun. 279, 615-620

Ohnesorge B., Trötschel B. and Deegen E. (1998) Bestimmung von Totraum und expiratorischem Mischvolumen zur Diagnostik chronischer Lungenerkrankungen beim Pferd. Pferdeheilkunde 14, 450-455

Olsen L., Ingvast-Larsson C., Bondesson U., Brostrom H., Tjalve H., Larsson P. (2007) Cetirizine in horses: pharmacokinetics and effect of ivermectin pretreatment. J. Vet. Pharmacol. Ther. 30, 194-200

Olszewski M. A., Robinson N. E., Zhu F. X., Zhang X. Y. and Tithof P. K. (1999a) Mediators of anaphylaxis but not activated neutrophils augment cholinergic responses of equine small airways. Am. J. Physiol. 276, L522-529

Olszewski M. A., Zhang X. Y. and Robinson N. E. (1999b) Pre- and postjunctional effects of inflammatory mediators in horse airways. Am. J. Physiol. 277, 327-333

Perkins G. A., Viel L., Wagner B., Hoffman A., Erb H. N. and Ainsworth D. M. (2008) Histamine bronchoprovocation does not affect bronchoalveolar lavage fluid cytology, gene expression and protein concentrations of IL-4, IL-8 and IFN-gamma. Vet. Immunol. Immunopathol. 126, 230-235

Ressemeyer A. R., Larsson A. K., Vollmer E., Dahlen S. E., Uhlig S. and Martin C. (2006) Characterisation of guinea pig precision-cut lung slices: comparison with human tissues. Eur. Respir. J. 28, 603-611

Schwalfenberg B. (2007) Untersuchung der Leukotrienwirkung am Pferdebronchus mittels "precision-cut lung slices” (PCLS). Diss. Med. Vet. Hannover

Seehase S., Schlepütz M., Switalla S., Mätz-Rensing K., Kaup F. J., Zöller M., Schlumbohm C., Fuchs E., Lavenstein H. D., Winkler C., Kuehl A. R., Uhlig S., Braun A., Sewald K. and Martin C. (2011) Bronchoconstriction in nonhuman primates: a species comparison. J. Appl. Physiol. 111, 791-798

Traub P. M. (2005) Klinische und immunologische Untersuchungen zur Ausprägung der Chronisch Obstruktiven Bronchitis des Pferdes: Gibt es Hinweise auf eine hyperreagible und eine dyskrinische Form? Diss. Med. Vet. Hannover

Vietmeier J., Niedorf F., Bäumer W., Martin C., Deegen E., Ohnesorge B. and Kietzmann M. (2007) Reactivity of equine airways - A study on Precision-cut Lung Slices. Vet. Res. Comm. 31, 611-619

Wellmann B. (2007) Klonierung und pharmakologische Charakterisierung des equinen Histamin H1 -Rezeptors. Diss. Med. Vet. München

Wohlsen A., Uhlig S. and Martin C. (2001) Immediate allergic response in small airways. Am. J. Respir. Crit. Care Med. 163, 1462-1469

Zerpa H., Berhane Y., Elliott J. and Bailey S. R. (2007) Cooling augments vasoconstriction mediated by $5-\mathrm{HT} 1$ and alpha2-adrenoceptors in the isolated equine digital vein: involvement of Rho kinase. Eur. J. Pharmacol. 569, 212-221

\author{
Dr. Ann Kristin Barton \\ Freie Universität Berlin \\ Klinik für Pferde \\ Oertzenweg $19 b$ \\ 14163 Berlin \\ kristin.barton@fu-berlin.de
}

